Olga Panić Kavgić*

UDC 371.3::811.111'243.378.4:[316.72

Aleksandar Kavgić

Faculty of Philosophy

DOI: $10.19090 /$ gff.2020.5.251-279

University of Novi Sad

Originalni naučni rad

\title{
ELEMENTS OF POPULAR CULTURE IN TEACHING SENTENCE PATTERNS AND VERBAL CATEGORIES TO STUDENTS OF ENGLISH LANGUAGE AND LITERATURE ${ }^{* *}$
}

The paper deals with the application of elements of present-day popular culture in teaching certain elements of grammar to first-year undergraduate students of English Language and Literature at the Faculty of Philosophy, University of Novi Sad. Preceded by a theoretical discussion of implicit/explicit and descriptive/prescriptive grammar teaching at the university level, the paper introduces elements of popular culture as a motivating factor and connective tissue to teach numerous grammar rules otherwise often perceived by students as uninteresting and difficult to understand, memorize and apply. In order to illustrate and reinforce the point that grammar is made more comprehensible when its rules and principles, their correct or incorrect use, are explained through examples from present-day popular culture, a selection of language units is extracted from films, cartoons, comic strips, TV series, talk shows and song lyrics, most of which are well-known to Millennial students. Employing qualitative methodology, various uses of elements of popular culture implemented in teaching grammar are extensively described and analyzed, while two of the students' answers in the e-survey were also analyzed quantitatively. This research is expected to demonstrate, explain and systematize the various ways in which the teaching process exploits grammatically relevant examples from widely known works of contemporary popular culture. The authors' presumptions about the effectiveness of introducing elements of popular culture are reinforced by the results of a short survey carried out in order to obtain feedback from students who attended the courses English Grammar 1 and English Grammar 2.

Key words: teaching grammar, English, popular culture, undergraduate grammar course, sentence pattern, verb phrase, grammar rule, student feedback

*olgapk@ff.uns.ac.rs

** This paper is part of the research on Project No. 178002, entitled Languages and Cultures in Time and Space, which is funded by the Serbian Ministry of Education, Science and Technological Development. 


\section{INTRODUCTION}

"A brief reference to popular culture led to momentary disruption of the norms, roles, and discourse customary in Ms. Leigh's classroom. [...] Ms. Leigh's reference to the televised talent show $X$ Factor (U.K. counterpart of American Idol) was received by a number of students with enthusiastic exclamations. [...] This was the first time Ms. Leigh had introduced $X$ Factor into her classroom, and we were intrigued by students' immediate and positive responses to the mere mention of the televised talent show." (Lefstein-Snell, 2011: 40)

Following the idea and its successful realization presented by Lefstein and Snell (2011), the topic of this paper is the application of elements of present-day popular culture in teaching elements of grammar (sentence patterns and verbal categories) to first-year undergraduate students of English Language and Literature, based on the authors' eighteen-year experience in teaching and testing English grammar at their home institution.

\subsection{Aims and hypothesis of the research}

This research is expected to demonstrate and explain the various ways in which the teaching process exploits grammatically significant and relevant examples from widely known works of contemporary popular culture, such as Star Wars, Game of Thrones, South Park, Friends, The Big Bang Theory, talk shows with Stephen Colbert, Jimmy Kimmel, Trevor Noah, or lyrics of songs performed by $20^{\text {th }}$ - and $21^{\text {st }}$-century music stars.

The initial hypothesis is that elements of popular culture are applicable and useful in teaching grammar both implicitly and explicitly, as well as descriptively and prescriptively, since they represent a strong motivating factor and connective tissue when it comes to acquiring numerous grammar rules. This view is in line with Duff and Zappa-Hollman's (2013) observation that "pop culture by definition is a vernacular form of culture that has immediacy, currency, and cachet providing students symbolic, social, and cultural capital in their encounters with others" (Duff-Zappa-Hollman, 2013: 5997). Elements of popular culture are here seen as an auxiliary device, a helpful tool alongside the necessary use of more traditional teaching and reading materials, such as grammar books, workbooks, dictionaries and other reference books. This view will be reinforced in Section 4 by the results of an e-survey carried out with students who, within the past five years, attended the reformed grammar courses described in Section 1.3. 
For the purpose of illustrating and reinforcing the point of this paper that grammar is made easier, more interesting and more comprehensible when its rules and principles, their correct or incorrect use, are explained through examples found in present-day popular culture, a selection of phrases and sentences has been extracted from films, cartoons, comic strips, cartoon drawings, TV series, talks shows and popular songs, most of which are well-known to Millennial students in Serbia. Such illustrative examples of language are then shown alongside accompanying pictures, photographs, captions and/or audio or video clips from the chosen works of popular culture. For instance, it has been proven in the authors' long experience in teaching and testing grammar that the semantic role of the patient is better remembered by students if, in class, they are given the famous sentence regularly occurring in the cartoon South Park: "Oh my God, they killed Kenny!", accompanied by the expected visual representation of the unfortunate little boy in the famous orange anorak. This assumption, as will be seen in Section 4 , is also corroborated by the results of a short e-survey carried out to obtain feedback from students who attended the courses English Grammar 1 and English Grammar 2 in the period between 2015 and 2019.

\subsection{Teaching grammar to undergraduate students of English Language and Literature}

The two core one-semester first-year undergraduate courses for students of English Language and Literature covering topics in English grammar at the authors' home institution are English Grammar 1 and English Grammar 2. The two complementary courses are taught one after the other over the course of two adjacent semesters through two weekly practice classes and theoretically oriented lectures. The basic required reading materials for both courses include selected sections of A Student's Grammar of the English Language (Greenbaum-Quirk, 1990) and, for practice classes, A Student's Workbook of English Grammar (ĐurićŠević, 2006), which is, to a large extent, based on Đurić and Šević (2001), and, to a lesser, on Chalker (1992) and Close (1974). In addition, exercises and theoretical notions from Vince and Sunderland (2003), Swan (2005) and Hewings (2013) are also included in the study materials. The two grammar courses have been taught in their current form since the introduction of the new curriculum at the Department of English Studies at the Faculty of Philosophy in Novi Sad in 2006, coinciding with the implementation of the Bologna Process into the system of higher education in Serbia, whose initial impact on studies of grammar at the university level is discussed in Novakov (2012). 
The courses English Grammar 1 and English Grammar 2 cover a wide range of theoretically founded and practically explored topics at the C1 (CEFR) level and are intended to equip students with a sound basis for acquiring further knowledge in the field. Starting from the unit titled Basic Concepts in Grammar, English Grammar 1 introduces the discussion of phrases in the English language through units Verbs and the Verb Phrase and Nouns, Pronouns and the Noun Phrase. The second course English Grammar 2, complementary to the previous one, consists of the following sections: Adjectives and Adverbs, Prepositions and the Prepositional Phrase, Adverbials: Adjuncts, Conjuncts and Disjuncts, The Simple Sentence and The Complex Sentence.

Understandably, the listed teaching and reading materials mostly place emphasis on explicit explanations of prescriptive aspects of standard English. On the other hand, examples from TV shows, songs etc. are either standard or partly informal/slang. This is why, as will be seen in Section 3, students are first acquainted with the notion of 'grammars' as opposed to the one and only 'grammar'. i.e. the standard variety of the formal register vs that of the informal interpersonal register of everyday communication.

The authors' strong conviction and, at the same time, the stated hypothesis of this paper is that better results in the teaching process would be achieved through expansion and enrichment of such, indisputably necessary, explicit and prescriptive foundations by means of certain carefully chosen, implicitly explained and, sometimes, descriptively underpinned phenomena in modern English, both formal and informal.

\subsection{Implicit teaching and descriptive approach to grammar through popular culture}

Prior to any discussion on introducing elements of popular culture into the teaching process, it is important to define two dichotomous pairs of terms and concepts inextricably linked to grammar instruction - namely, explicit vs implicit, and descriptive vs prescriptive approaches. In this respect, Bodrič (2018) differentiates between the concepts of 'formS' and 'forms', the former referring to explicit, and the latter to implicit teaching. According to Bodrič (2018), "focus on formS advocates the explicit teaching of grammatical forms, namely the formal explanation of rules; focus on forms, on the other hand, involves the implicit teaching of grammatical forms through contextualized discourse, thereby emphasizing meaning and communication" (2018: 7). With no intention to favour either approach, it is not difficult to infer that introducing contextualized elements 
of popular culture may enhance the one putting greater emphasis on 'forms', i.e. on implicit teaching practices.

Furthermore, if one adopts the simplest general definition of any prescriptive approach as "telling people what they should do, rather than simply giving suggestions or describing what is done", at the same time bearing in mind the sometimes notorious reputation of prescriptive attitudes to language, prescriptive grammar is actually about how the rules of language ought to be applied, i.e. about prescribing its correct use. On the other hand, descriptive grammar focuses on describing language as it is used, and not necessarily saying how it should be used. It would thus include both, strictly speaking, prescriptively correct and incorrect uses of language, as well as a certain number of what one might label "borderline cases". Regardless of the utmost importance of acquiring the rules of prescriptive grammar and giving them priority over their less standardized counterparts, especially by university students who are preparing to teach the self-same rules to their prospective pupils, it should still be stressed that modern linguistics insists on acknowledging there are different "grammars" of English that a future teacher must be aware of. In fact, there are broadly two types of "grammars" in every language: the grammar of the standard variety of a language and various grammars of its non-standard and colloquial varieties. Therefore, description, supported by contextualized examples from popular culture, deserves its place in the process, as an addition to and in parallel with presenting the prescriptive rules, which, in turn, can equally well be supported by chunks of language found in popular culture - a concept that will be defined in the following section.

\subsection{Popular culture as a concept and its application in the language classroom}

The term 'popular culture' was coined in the $19^{\text {th }}$ century or, according to some sources, even earlier. Traditionally, it was associated with poor education and the lower classes, as opposed to the "official culture" and higher education of the upper classes. In simple terms, making reference to appealing to the popular taste, Longman Dictionary of Contemporary English defines popular culture (or mass culture, or pop culture) as "the music, books, films etc. that are liked by a lot of people".

Authors in the field of applied linguistics have also attempted to define the phenomenon in order to discuss its application in language teaching and learning. One of the most applicable accounts of what popular culture would include in this domain is provided by Duff and Zappa-Hollman (2013): 
"Although popular culture is pervasive in contemporary Western and other highly urbanized, postindustrial societies impacted by globalization, it can be difficult to define and delimit the term. That is because popular culture means different things - both theoretically and practically - to different people [...] Television programs, commercials, movies, sports broadcasting, radio programming, hip-hop, online media, blogs, YouTube, concerts and poetry slams, computer games and simulations, comic books and trade fiction, and various social media, texting tools, and clothing fashions can all be considered contemporary manifestations of popular (pop) culture - usually with mass (commercial) appeal and relevance to large swaths of the population" Duff and Zappa-Hollman (2013: 5997).

Adopting a non-elitist stance that certain elements of high culture, such as lines from famous opera libretti or quotes from classical works of fiction, may also be viewed as popular, in this research the concept would mostly include categories such as entertainment (television, film, music, video games, comic strips), politics and products of modern technologies, not all of which necessarily represent a 'lower' variety when contrasted with high culture which frequently enters the realm of the popular. In other words, popular culture encompasses extralinguistic references that permeate our daily lives to the extent that they become integral parts of our internal and external perceptions of the world we live in, in terms of memorable symbols of shared experience common to an entire generation.

When it comes to its application in language teaching practices, popular culture has only recently been recognized as an important tool and a successful auxiliary device. It has undergone a change in perception in the language-learning community starting from the late 1970s. Having been initially frowned upon, popular culture in the late 1970s and during the 1980s started being embraced first as a means for students to "sharpen their awareness of the influence of high and low cultures upon the popular culture" (Kirby, 1978: 34). Towards the end of the 1990s, popular culture was seen as a welcome addition to EFL textbooks in the context of increasing intercultural competences by a focus on culture, which was regarded as a means to achieve communication ends (Cortazzi-Lin, 1999: 218-219). In the 2000s, popular culture also started to be viewed as a means to modify EFL methodology so that it could be "amended and adapted to fit the needs of the students" (Harmer, 2003: 292) within the communicative approach. Finally, in the 2010s, popular culture is finally seen as a motivational resource in all EFL contexts that can be used to boost efficiency of learning in multiple domains (Luo, 2014: 209). For instance, Liu and Lin (2017) show the positive effects of using pop songs in the classroom. 
Having all this in mind, popular culture can nowadays be considered an established motivational tool and a means to boost intercultural competences in the general EFL teaching processes, but, as also noted by Liu and Lin (2017), more research should be done "to examine the efficiency of using popular culture in TESOL and to investigate when and for whom popular culture can be useful and in which dimensions of the language ability" (Liu-Lin, 2017: 11).

As can be deduced from most of the above-mentioned authors' overview of the traditional approach to the use of popular culture in EFL and TESOL, there is a lack of research on its applicability to teaching grammar, as a possible application of popular culture. Having this in mind, this paper also aims to make a modest contribution to fill the gap of "insufficient research in applied linguistics and language education documenting learning processes and outcomes in these creative spaces" (Duff and Zappa-Hollman, 2013: 6001).

Furthermore, it is mostly at the level of primary and secondary education that research has been carried out in the field, with other recent notable studies by Lefstein and Snell (2011), Hua and Li (2015), Rets (2016), Hofmann (2018), while authors in Serbia include Gajdoš and Korpaš (2019), Ćurčić (2016) and Marjanović (2017). Within a broader context of new tendencies in EFL teaching in Serbia, Dejić (2013), Dujić (2016) and Nedić (2014) also tackle the topic of popular culture in grammar instruction, while students' and teachers' attitudes towards new practices are elaborated in, among others, Graus and Coppen (2016), Phipps and Borg (2009), Glušac and Pilipović (2019) and Bodrič (2018).

This research will, hopefully, contribute to the idea that popular culture also has its place in teaching grammar to prospective language instructors and translators. To this avail, a body of representative and grammatically relevant examples, a small part of which will be used for illustrative purposes in this paper, has been collected through two decades of teaching experience at the undergraduate level of university education.

\section{RESEARCH CORPUS AND METHODOLOGY}

The corpus for this research consists of grammatically relevant examples ${ }^{1}$ from widely known works of popular culture and entertainment, including:

\footnotetext{
${ }^{1}$ Examples from the listed sources are all used in class, incorporated into Power Point presentations accompanying weekly oral lectures in English Grammar 1 and English Grammar 2. In this paper, however, only a small number of representative examples will be
} 
- films and movie franchises (Star Wars, Star Tracks, Lord of the Rings, Harry Potter, Indiana Jones, Jaws, Batman, Back to the Future...)

- TV series (South Park, The Simpsons, Friends, Game of Thrones, The Big Bang Theory, How I Met Your Mother, Only Fools and Horses, Stranger Things...)

- feature-length animated films (Toy Story, Finding Nemo, Frozen, Beauty and the Beast, Shrek, The Croods, Home, Inside Out, Zootopia, Alice in Wonderland...)

- film titles and promotional taglines ${ }^{2}$

- documentaries (Planet Earth, The Blue Planet, An Inconvenient Truth...)

- comic strips (Hi \& Lois, Dilbert, Marvel comics...)

- cartoon drawings (CartoonStock...)

- transcripts of and clips from late night shows with Stephen Colbert, Jimmy Kimmel, Jimmy Fallon, James Corden, Trevor Noah and Ellen DeGeneres

- lyrics of popular songs (The One that Got Away - Katy Perry, Wildest

Dreams - Taylor Swift, Sound of Silence - Simon and Garfunkel,

Satisfaction - The Rolling Stones, Summer Wine - Nancy Sinatra and Lee Hazlewood...)

Illustrative phrases, clauses and sentences from the selected sources are in class regularly accompanied by audio-visual material such as pictures, photographs, captions, video clips and music recordings. Understandably, for reasons of technical and medium-related nature, this paper will only contain selected static and visual instances of the listed in-class materials.

The methodology employed in this paper is mainly qualitative, as it consists in describing and exemplifying various uses of elements of popular culture implemented in teaching certain elements of grammar to undergraduate university students. In other words, it represents an attempt at collecting, organizing, describing and interpreting a particular kind of textual and/or visual aids in the teaching process. The results of the e-survey carried out to obtain feedback by some of the former students who attended the two grammar courses, further discussed in Section 4, will be analyzed both quantitatively and qualitatively, by means of

presented in Section 3. The relevancy of the examples refers to the fact that, structurally, semantically and/or functionally, they fit the requirements of the topic discussed in class.

${ }^{2}$ Huge corpora of five thousand film titles and nine hundred taglines also used in this study were initially collected by Panić Kavgić (2014) and Panić Kavgić and Kavgić (2018), respectively. 
providing percentual data about the answers to two Likert-scale questions, and by commenting on the most representative answers to the third, open-ended question.

\section{EXAMPLES FROM POPULAR CULTURE IN TEACHING GRAMMAR}

Representative examples from popular culture will here be given for phenomena related to the topics Basic Concepts in Grammar and Verbs and the Verb Phrase, which represent the first two units of the undergraduate university course Grammar of English 1 at the Department of English Studies, at the Faculty of Philosophy in Novi Sad. The initial idea was to provide examples from all the units listed in Section 1.2, both within English Grammar 1 and English Grammar 2, but due to the restrictions on the scope of the paper, this section will focus only on cases of popular culture utilized in the first three units. Therefore, the topics covered will include the following: grammar of standard language vs grammars of non-standard varieties; syntactic constituents; grammatical ambiguity; phrases and clauses as structural units; types of phrases in English; verbs, the verb phrase and verbal categories: tense, aspect, mood, voice and modality.

In the introductory stages of the course, one of the goals is to make students aware that even native speakers of English (or any other language for that matter, including Serbian) do not always abide by the norms of the standard variety and prescriptive grammar rules, which does not necessarily hinder normal communication, as the message most often still gets across, especially in the informal interpersonal register. In order to illustrate this point, students are reminded of famous lines of well-known song lyrics which contain deviations ${ }^{3}$ from the standard in different domains of grammar, such as the following examples in Table 1:

\footnotetext{
${ }^{3}$ A question may be raised as to why these deviations were used by the authors of the lyrics - the answer could be that there are various reasons, linguistic and non-linguistic ones, and that they may be more or less conspicuous. For instance, Lay Lady Lay might have seemed 'better' to Bob Dylan than Lie Lady Lie for the sake of achieving assonance, while 'Who you gonna call', a line from Ghostbusters would not meet the metrical requirements had it been 'Who are you going to call'. Similarly, 'bleeded' in Timberlake's song rhymes with 'cheated', which would not be the case with the correct form 'bled'. Other, probably sociolinguistic, reasons may account for the non-standard use of 'was' instead of 'were' in Hound Dog, 'do' instead of 'does' in a song by The Police, or the double negation in Satisfaction.
} 


\begin{tabular}{|c|c|c|}
\hline $\begin{array}{l}\text { SONG } \\
\text { AND PERFORMER }\end{array}$ & $\begin{array}{l}\text { THE } \\
\text { "UNGRAMMATICAL" } \\
\text { LINE IS... }\end{array}$ & $\begin{array}{l}\text { THE GRAMMATICALLY } \\
\text { CORRECT VERSION } \\
\text { SHOULD HAVE BEEN... }\end{array}$ \\
\hline $\begin{array}{l}\text { Satisfaction, } \\
\text { The Rolling Stones }\end{array}$ & I can't get no satisfaction & I can get no satisfaction \\
\hline $\begin{array}{l}\text { Lay Lady Lay, } \\
\text { Bob Dylan }\end{array}$ & $\begin{array}{l}\text { Lay lady lay } \\
\text { Lay across my big brass bed }\end{array}$ & $\begin{array}{l}\text { Lie lady lie } \\
\text { Lie across my big brass bed }\end{array}$ \\
\hline $\begin{array}{l}\text { Lay Down Sally, } \\
\text { Eric Clapton }\end{array}$ & $\begin{array}{l}\text { Lay down, Sally, } \\
\text { no need to leave so soon }\end{array}$ & $\begin{array}{l}\text { Lie down, Sally, } \\
\text { No need to leave so soon }\end{array}$ \\
\hline $\begin{array}{l}\text { Every Little Thing She Does } \\
\text { Is Magic, The Police }\end{array}$ & $\begin{array}{l}\text { Everything she do just turns } \\
\text { me on }\end{array}$ & $\begin{array}{l}\text { Everything she does just turns } \\
\text { me on }\end{array}$ \\
\hline $\begin{array}{l}\text { Hound Dog, } \\
\text { Elvis Presley }\end{array}$ & $\begin{array}{l}\text { When they said you was high } \\
\text { class... }\end{array}$ & $\begin{array}{l}\text { When they said you were high } \\
\text { class... }\end{array}$ \\
\hline $\begin{array}{l}\text { Ghostbusters, } \\
\text { Ray Parker, Jr. }\end{array}$ & $\begin{array}{l}\text { Who you gonna call? } \\
\text { Ghostbusters! }\end{array}$ & Who're you going to call? \\
\hline $\begin{array}{l}\text { Summer Wine, } \\
\text { Nancy Sinatra }\end{array}$ & $\begin{array}{l}\text { A song that I had only sang to } \\
\text { just a few }\end{array}$ & $\begin{array}{l}\text { A song that I had only sung to } \\
\text { just a few }\end{array}$ \\
\hline $\begin{array}{l}\text { What Goes Around ... Comes } \\
\text { Around, Justin Timberlake }\end{array}$ & $\begin{array}{l}\text { When you cheated, } \\
\text { my heart bleeded }\end{array}$ & $\begin{array}{l}\text { When you cheated, my heart } \\
\text { bled }\end{array}$ \\
\hline $\begin{array}{l}\text { I Don't Want to Wait, } \\
\text { Paula Cole }\end{array}$ & $\begin{array}{l}\text { So open up your morning light } \\
\text { and say a little prayer for I }\end{array}$ & $\begin{array}{l}\text { So open up your morning } \\
\text { light and say a little prayer for } \\
\text { me }\end{array}$ \\
\hline $\begin{array}{l}\text { Bad Romance, } \\
\text { Lady Gaga }\end{array}$ & $\begin{array}{l}\text { You and me could write a bad } \\
\text { romance }\end{array}$ & $\begin{array}{l}\text { You and I could write a bad } \\
\text { romance }\end{array}$ \\
\hline
\end{tabular}

Table 1: Non-standard vs standard grammar in popular song lyrics

Having been introduced to the basic concepts regarding standard grammar, students are acquainted with the notion of parsing the sentence: first, broadly, into Subject and Predicate, and then, more elaborately, into sentence elements, i.e. syntactic functions - the five syntactic constituents (Subject, Verb, Object, Complement and Adverbial) whose number and distribution determine the pattern of each particular sentence in English. This is presented in class through one of the most iconic situations involving Eric Cartman and Kenny from the subversive animated series South Park, as seen in Pictures 1-3: 


\section{SENTENCE ELEMENTS SYNTACTIC FUNCTIONS}

Eric Cartman killed Kenny with a knife.

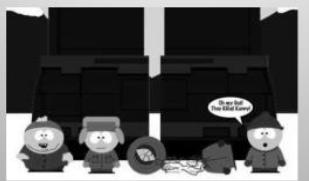

A general syntactic analysis of the sentence would yield the following syntactic structure:

$\mathbf{S}$ (Eric Cartman) + Predicate (killed Kenny with a knife)
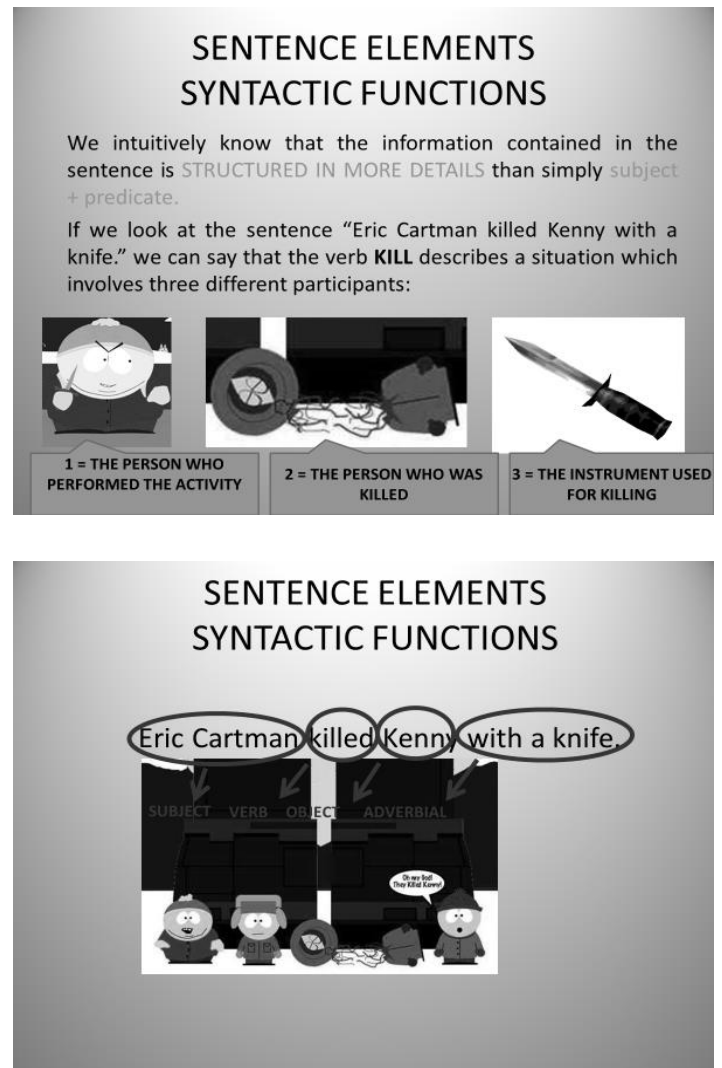

Pictures 1-3: From subject-predicate to syntactic constituents in "South Park"

Once the stage has been set for dividing any English sentence into its syntactic constituents, it is pointed out that their number and distribution, crucially determined by the verb category (intensive vs. extensive /intransitive, monotransitive, ditransitive or complex transitive/), may result in one of the seven 
possible sentence patterns based on its obligatory elements: SVC, SVA, SV, $\mathrm{SVO}_{\mathrm{d}}, \mathrm{SVO}_{\mathrm{i}} \mathrm{O}_{\mathrm{d}}, \mathrm{SVO}_{\mathrm{d}} \mathrm{C}, \mathrm{SVO}_{\mathrm{d}} \mathrm{A}$. These are represented through the following selected taglines and quotations from Oscar-winning or nominated films ${ }^{4}$ in Table 2 , with obligatory elements in square brackets and optional adverbials in parentheses:

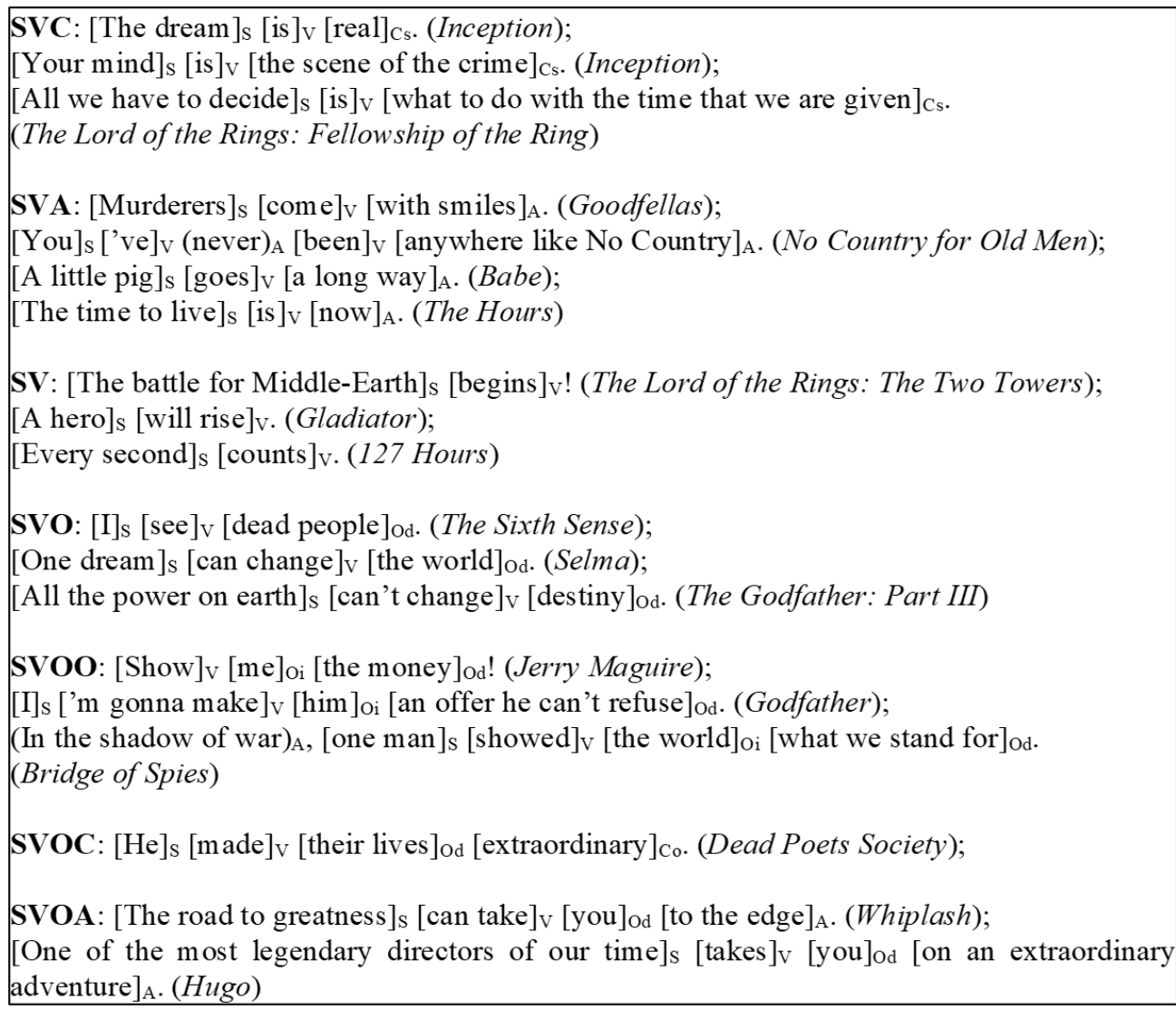

Table 2: Sentence patterns in English through examples of film taglines and quotations

${ }^{4}$ These taglines and quotations help the students to memorize the patterns more easily because they are rather well-known, some of them even ubiquitous (e.g. 'I see dead people' from The Sixth Sense), having entered the everyday language of any regular movie-goer. This would enable students to easier remember the sentence pattern itself (in this case SVO), once they have linked it to such a familiar quote which is not only immensely popular, but also short and simple. Subsequently, it would be easier for students to merely replace the elements $I$, see and dead people by any more complex elements and conclude that a sentence does or does not constitute an example of the SVO pattern. 
At this point it is reiterated that $\mathrm{S}, \mathrm{V}, \mathrm{O}$ and $\mathrm{C}$ are categorized in grammar as obligatory syntactic constituents (except in certain rare cases, such as, for example, the film title Dances with Wolves, which, for particular plot-based reasons, lacks a subject), while $\mathrm{A}$ is most often optional, in the sense that the sentence remains grammatically correct even if the adverbial is left out, regardless of the possible semantic implications, as in the following film taglines:

- (This Christmas) $)_{\mathbf{A}}$, Django is off the chain. (Django Unchained)

- (At the point of crisis) $)_{A}$, (at the point of annihilation) $)_{A}$, survival is victory. (Dunkirk)

- (In memory) $)_{\mathrm{A}}$, love lives (forever) $)_{\mathrm{A}}$. (The English Patient)

- (To enter the mind of a killer) $)_{\mathrm{A}}$ she must challenge the mind of a madman. (Silence of the Lambs)

- (When his nation needed a leader) ${ }_{\mathrm{A}}$, (when the people needed a voice) ${ }_{\mathrm{A}}$, an ordinary man would help him (find the courage) $)_{\mathrm{A}}$. (The King's Speech)

Even if the sentence completely changes its meaning, the adverbial is viewed as optional as long as the structure is grammatically acceptable. In other words, changes in meaning are grammatically irrelevant:

- One of the greatest heroes in American history (never) ${ }_{\mathrm{A}}$ fired a bullet. (Hacksaw Ridge)

- The world will (never) be the same (once you've seen it through the eyes of Forrest Gump) $)_{\mathrm{A}}$. (Forrest Gump)

- You don't get to 500 million friends (without making a few enemies) A $_{\mathrm{A}}$. (Social Network)

The importance of the verb category for shaping the sentence pattern is best comprehended based on the multiple class membership of the verb get, as observable in the following movie titles: Get Hard (SVC), Get Smart (SVC or SVO), Jane Got a Gun (SVO), Get Yourself a College Girl (SVOO), Get Him to the Greek (SVOA), They Got Me Covered (SVOC). The second example, Get Smart, shifts the discussion in the direction of dealing with grammatical ambiguity intended by the creators of the film and its title. Two other interesting instances of grammatically ambiguous titles are Hope Springs (an SV clause, or a noun phrase the name of the spa resort), and Fear $X$ (an (S)VO clause, or a noun phrase designating unknown fear). To round up the discussion of verb categories and their consequent sentence patterns, a title is used to explain how easily one can ascribe misattributed ambiguity to a structure originally not intended to be equivocal. Namely, Death Becomes Her might at first be interpreted as an instance of the SVO 
pattern, and, yet, it is only intended to be understood as SVC, based on the plot in which two women undergo lethal surgical treatment that permanently alters their appearance. Finally, grammatical ambiguity in everyday language is exemplified in Picture 4, through a Hi \& Lois comic strip:

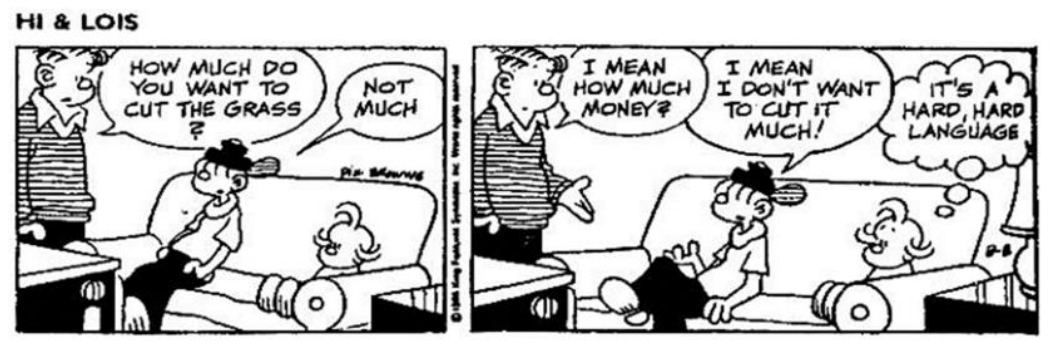

Picture 4: Grammatical ambiguity in "Hi \& Lois"

The discussion of syntactic functions and potential ambiguities is followed by the introduction of the concept of syntactic forms - phrases and clauses, with a one-to-one correspondence between a function and a form, in the sense that one function $(\mathrm{S}, \mathrm{V}, \mathrm{O}, \mathrm{C}$, or $\mathrm{A}$ ) is structurally realized as one form (a phrase $-\mathrm{NP}, \mathrm{VP}$, AP, AdvP or PP, or a clause - nominal or adverbial), albeit not always the same one. An adverbial can, for instance, be realized as an AdvP, a PP, an NP or an adverbial clause. Phrases are defined as words grouped around a head word - the most important element that is modified or complemented by the other words in a phrase. How a phrase of varying length and complexity (in this case, a noun phrase) could be substituted by a single short pro-form (in this case, a pronoun) is shown to the students in Picture 6, as they are reminded of the head of the Simpson family:

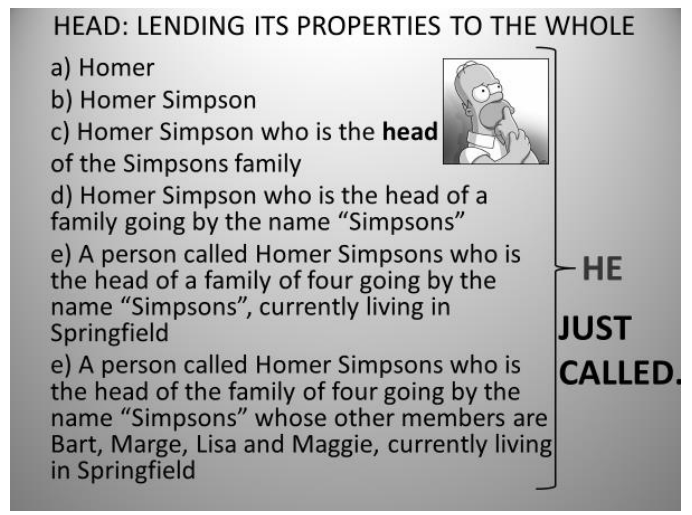

Picture 5: Phrase headedness exemplified by the head of the Simpson family 
The first type of phrase analysed in the course English Grammar 1 is the Verb Phrase. Preceded by a discussion of the verbal paradigm and its five forms, the verbal categories of tense, aspect, mood, voice and modality are introduced with special emphasis on the difference between time as a universal non-linguistic concept and tense as a linguistic category that "locates the situation somewhere on the timeline" (Đurić-Šević, 2006: 38). At this point students are made aware that English makes a distinction only between the Present and the Past Tense, while future is never labelled as 'tense', but as 'Future Time' - both due to linguistic reasons of morphological nature (lack of inflections) and to the non-linguistic, highly speculative and uncertain, nature of future activities. Here students are reminded of the main premise of the Hollywood blockbuster Minority Report, a dark dystopian view of the world with an underlying philosophical message about the unpredictability of future events. On a brighter note, speculating about the future is shown as being in the domain of self-confessed mediums and other charlatans who, like in Picture 6, claim to be able to predict events, even using the be going to structure, as if they were based on present causes that would almost inevitably have predictable future consequences:

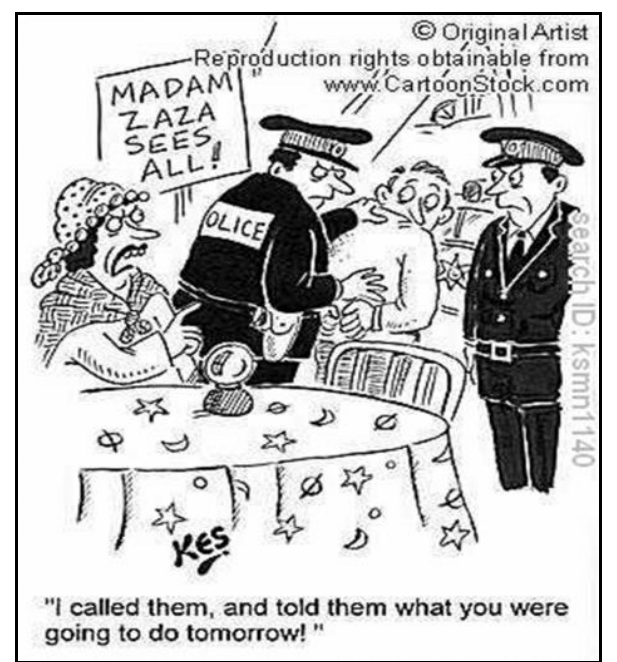

Picture 6: The future is (not) foreseeable, what is going to happen?

On the other hand, aspect is determined as "viewing the internal temporal structure of the situation" (Đurić-Šević, 2006: 38) and its combinations with tense yield constructions specific to the English language, such as the Present Perfect with its various uses and meanings, listed in Table 3. Aided by accompanying 
video-clips ${ }^{5}$, different uses of the Present Perfect are exemplified through excerpts from films and music clips:

\begin{tabular}{|c|c|c|}
\hline $\begin{array}{l}\text { MEANING AND USE OF } \\
\text { THE PRESENT PERFECT }\end{array}$ & EXAMPLE & $\begin{array}{l}\text { WORK OF POPULAR } \\
\text { CULTURE }\end{array}$ \\
\hline \multirow[t]{3}{*}{ EXPERIENTAL PERFECT } & $\begin{array}{l}\text { A: He's your uncle? } \\
\text { B: Him? Uh-uh. I've never } \\
\text { seen him before. }\end{array}$ & $\begin{array}{l}\text { Mickey's Twice upon a } \\
\text { Christmas, } \\
\text { Walt Disney Pictures }\end{array}$ \\
\hline & I've never been sick before. & $\begin{array}{l}\text { Jack Nicholson in The Bucket } \\
\text { List, Warner Bros. et al. }\end{array}$ \\
\hline & $\begin{array}{l}\text { Have you ever imagined a } \\
\text { future with me? }\end{array}$ & $\begin{array}{l}\text { Penelope Cruz in Elegy, } \\
\text { Lakeshore Entertainment }\end{array}$ \\
\hline \multirow[t]{2}{*}{ RECENT PAST USE } & $\begin{array}{l}\text { Hello, darkness, my old friend. } \\
\text { I've come to talk to you } \\
\text { again. }\end{array}$ & $\begin{array}{l}\text { Sound of Silence, } \\
\text { Simon and Garfunkel }\end{array}$ \\
\hline & I've come to say good-bye. & $\begin{array}{l}\text { Back to the Future Part III, } \\
\text { Universal Pictures }\end{array}$ \\
\hline \multirow[t]{5}{*}{ PRESENT RESULT } & $\begin{array}{l}\text { I've made changes for you, } \\
\text { Shrek. Think about that. }\end{array}$ & $\begin{array}{l}\text { Shrek 2, } \\
\text { DreamWorks }\end{array}$ \\
\hline & Alice has escaped. & $\begin{array}{l}\text { Alice in Wonderland, } \\
\text { Walt Disney Pictures }\end{array}$ \\
\hline & $\begin{array}{l}\text { I've made a decision. We are } \\
\text { going up that mountain. }\end{array}$ & $\begin{array}{l}\text { The Croods, } \\
\text { DreamWorks Animation }\end{array}$ \\
\hline & $\begin{array}{l}\text { The maniac Boov has ruined } \\
\text { everything. This is bad. }\end{array}$ & $\begin{array}{l}\text { Home, } \\
\text { DreamWorks Animation }\end{array}$ \\
\hline & $\begin{array}{l}\text { Something wonderful has } \\
\text { happened. Ani, I'm pregnant. }\end{array}$ & $\begin{array}{l}\text { Natalie Portman in } \\
\text { Star Wars: Revenge of the Sith: } \\
\text { Episode III, Lucasfilm }\end{array}$ \\
\hline \multirow[t]{2}{*}{ DURATION UP TO NOW } & $\begin{array}{l}\text { A: How long has he been } \\
\text { gone? B: Two weeks, one day, } \\
15 \text { hours. }\end{array}$ & $\begin{array}{l}\text { Batman: Bad Blood, } \\
\text { Warner Bros. Animation }\end{array}$ \\
\hline & I've missed you so much. & $\begin{array}{l}\text { How I Met Your Mother, } \\
\text { Season 2, Episode } 7 \text {, } \\
20^{\text {th }} \text { Century Fox Television }\end{array}$ \\
\hline $\begin{array}{l}\text { DURATION UP-TO-NOW + } \\
\text { PRESENT RESULT }\end{array}$ & $\begin{array}{l}\text { Their mother has not eaten } \\
\text { for five months and has lost } \\
\text { half of her body weight. }\end{array}$ & $\begin{array}{l}\text { Planet Earth: From Pole to } \\
\text { Pole, } \mathrm{BBC}\end{array}$ \\
\hline $\begin{array}{l}\text { PRESENT RESULT + } \\
\text { EXPERIENTIAL PERFECT }\end{array}$ & $\begin{array}{l}\text { And when we've had our } \\
\text { very last kiss } \\
\text { But my last request is... }\end{array}$ & $\begin{array}{l}\text { Wildest Dreams, } \\
\text { Taylor Swift }\end{array}$ \\
\hline
\end{tabular}

Table 3: The Present Perfect, its meanings and uses: examples primarily based on "Best Examples of Present Perfect Tense - Learn and Teach English with Videos"

${ }^{5}$ There are certain visual segments of context that are helpful in determining a particular use of the Present Perfect. For instance, students are shown a clip from a documentary, of a polar bear before and after a five-month period of starvation. This provides for a perfect visual accompanying device to the sentence 'Their mother has not eaten for five months and has lost half of her body weight' and an excellent illustration of combining the following two uses of the Present Perfect: duration up-to-now and present result. 
Another phenomenon pertaining to the category of aspect (perfective or progressive) is its relation with tense and whether the focus is on the structure of the activity, its outcome or the time of the activity, all of which are expressed by means of different tense-aspect combinations. This can be observed through the varying "behaviour" of the iconic Pixar Animation Studio's symbol - the jumping Luxo lamp and its notorious squashing of the I letter as part of the opening credits to Pixar movies, which can be seen in Pictures 7-9, representing captions from short animated videos:
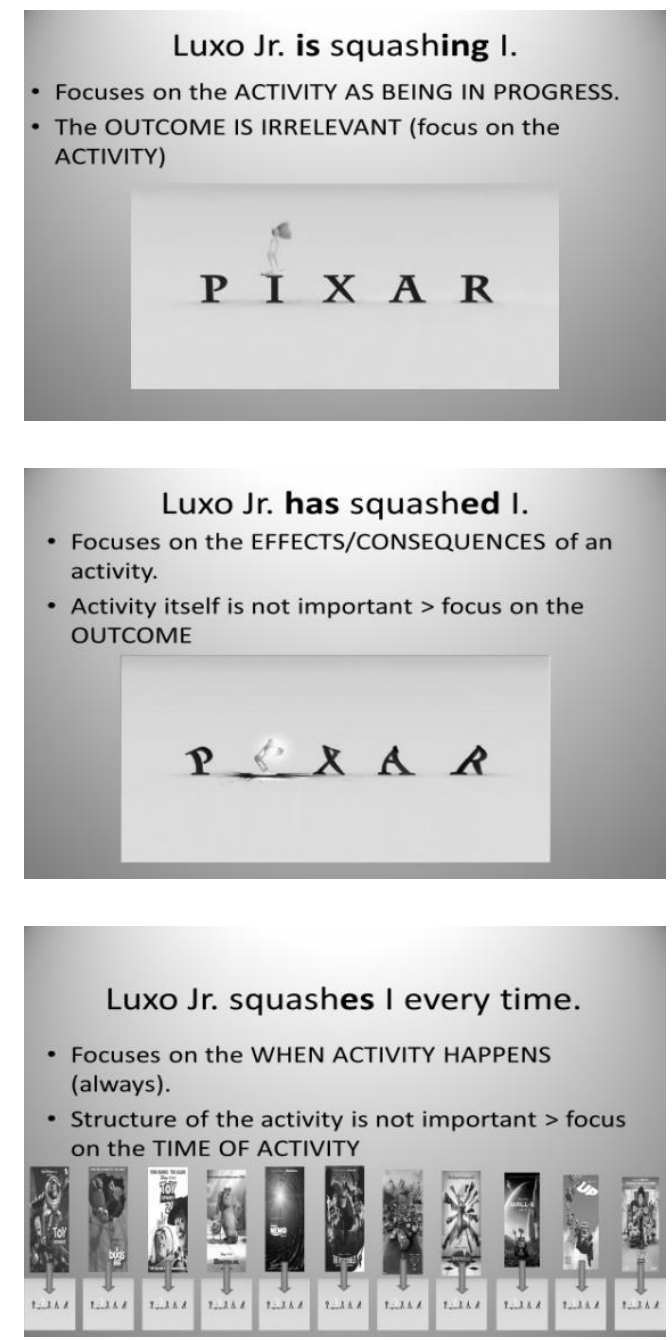

Pictures 7-9: Tense-aspect combinations: focus on activity, outcome and time with Pixar's Luxo 
In addition to discussing and exemplifying two other verbal categories that students are relatively familiar with (voice and modality), mood proves to be somewhat more obscure, especially the subjunctive, which does not exist as such in the Serbian language, although there are structures conveying similar meanings. Instances of the present subjunctive (mandative and formulaic) and past subjunctive (the universal were form in hypothetical contexts, with its widely used informal modal-past variation was) are presented to students through lines from Kate Perry's The One That Got Away, Beyoncé's If I Were a Boy and Jon Bon Jovi's If I Was Your Mother ${ }^{6}$ :

In another life, I would be your girl, we keep all our promises, be us against the world... If I were a boy, even just for a day...

*If I was your mother, would you let me hold your hand...

The unit about verbs and verb phrases would not be complete without tackling the often elusive issue of finiteness - a category which students are required to comprehend in order to later cope with the structure and typology of clauses. Announcing the topic of finiteness with the popular film title What to Expect When You're Expecting, which contains both a non-finite and non-finite VP (and, for that matter, a finite and non-finite clause), the students' expectations regarding this category are hopefully set in the expected direction: non-finite VPs in English, which, unlike finite ones, "do not show agreement with their subject (which is regularly omitted) and can only be marked with the categories of aspect and voice" (Đurić-Šević, 2006: 32), include participial and infinitival structures the present and past participle and the bare and to-infinitive. When it comes the former, it is of utmost importance to distinguish between the clausal (in non-finite clauses) and adjectival uses of the so-called $\mathrm{V}_{\text {ing }}$ (present participle) and $\mathrm{V}_{\text {ed2 }}$ (past participle) forms, which are exemplified by the following film titles in Table 4:

\footnotetext{
6 The purpose of using these and similar examples, in addition to memorizing them more easily and then recognizing that other similar examples belong to the same verbal category, is that students are, probably for the first time, made (and motivated) to pay attention to such structures and think about them in terms of the grammar rules they have acquired. Since the subjunctive mood has never been dealt with in either primary or secondary school, at least not formally, it is through these lines that students are made aware that there is another verbal category in addition to tense, aspect and voice, and that they can encounter its application in similar frequently used expressions such as be that as it may.
} 


\begin{tabular}{|l|}
\hline Ving forms in non-finite clauses of various patterns: \\
\hline (S)VO: Finding Nemo, Saving Private Ryan, Driving Miss Daisy, Leaving Las Vegas, Breaking the \\
Waves, Loving Vincent, Deconstructing Harry, Chasing Amy, Man Seeking Woman, Seeking a \\
Friend for the End of The World \\
\hline (S)VA: Bowling for Columbine, Playing by Heart, Sleeping with the Enemy, Being There \\
\hline (S)VC: Being Julia, Being John Malkovich, Becoming Jane \\
\hline (S)V: Searching, Loving \\
\hline $\mathbf{V}_{\text {ing forms in their adjectival use: }}$ \\
\hline $\begin{array}{l}\text { NP: (Det) + Adj + Nhead: Stealing Beauty, Raging Bull, Missing Link, The Running Man, The } \\
\text { Shipping News, The Crying Game }\end{array}$ \\
\hline $\mathbf{V}_{\text {ed2 } \text { forms in non-finite clauses of various patterns: }}$ \\
\hline (S)VA: Born on the Fourth of July, Lost in Translation, Gone with the Wind \\
\hline (S)V: Taken, Wanted, Shattered \\
\hline$V_{\text {ed2 }}$ forms in their adjectival use: \\
\hline $\begin{array}{l}\text { Lost Girls, Hidden Figures, Missed Connections, Broken Flowers, Shattered Glass, The Lost Citz } \\
\text { of Z, The Hurt Locker }\end{array}$ \\
\hline$V_{\text {ing }}+V_{\text {ed2 } \text { forms in their adjectival use: Crouching Tiger, Hidden Dragon }}$ \\
\hline
\end{tabular}

Table 4: The present and past participle forms and their clausal and adjectival uses

To-infinitives and, somewhat less frequently, bare infinitives, also have their place in film title-formation. They can, at the same time, be viewed as nonfinite participial clauses, from the syntactic point of view:

To-infinitive non-finite clauses: How to Train Your Dragon, How to Be Single, How to Get Away with Murder, How to Make an American Quilt, Where to Invade Next, Fantastic Beasts and Where to Find Them

Bare-infinitive + to-infinitive non-finite clauses: Why Bother to Knock

The last lecture of the course English Grammar 1 ends with the following entertaining motivator (Picture 10), reminding students that they will have covered all important aspect of English grammar and will have reached "the top" once they have completed attendance of the course English Grammar 2 in the following semester: 


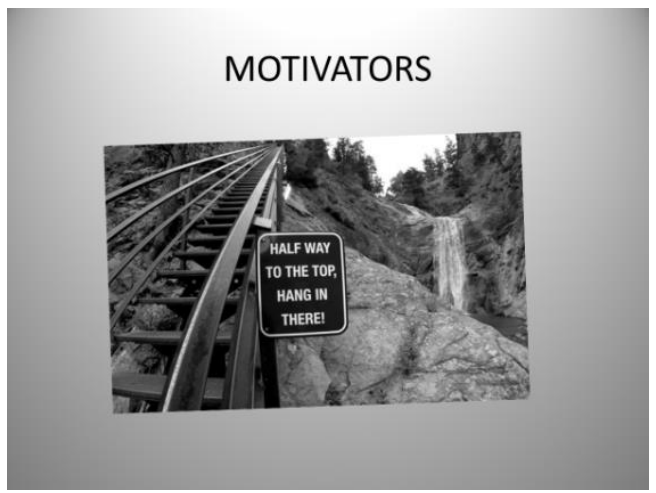

Picture 10: End-of-semester motivator

\section{STUDENT FEEDBACK}

A short e-survey was carried out in June 2020 in order to obtain feedback from students who attended the courses English Grammar 1 and English Grammar 2 in the period between October 2015 and June 2019. A three-part questionnaire was sent by e-mail to the addresses of 107 students, 58 of whom replied and filled out the questionnaire. The aim of the survey was to corroborate the hypothesis that introducing elements of popular culture in teaching English grammar to students of English Language and Literature was a facilitative innovation that students found welcome and more interesting than the more traditional method they had been, presumably, exposed to in the course of their primary and secondary education.

The first two questions required an answer on the so-called Likert scale - a five-point scale, sometimes also referred to as a satisfaction scale, that ranges from one extreme attitude to another:

1) To what extent were lectures in English Grammar 1 and English Grammar 2 similar to English grammar classes in the course of your previous education? They were:

1 - almost identical; 2 - similar; 3 - neither obviously similar nor different; 4 different; 5 - completely different

2) To what extent were lectures in English Grammar 1 and English Grammar 2 interesting when compared to English grammar classes in the course of your previous education? They were:

1 - considerably more boring; 2 - more boring; 3 - the same; 4 - more interesting; 5 - considerably more interesting 
The first question yielded the following results: 18 students $(\approx 31 \%)$ found the university lectures completely different from English grammar classes in the course of their previous education, $31(\approx 54 \%)$ thought they were different, 6 $(\approx 10 \%)$ answered that they were neither obviously similar nor different, while 3 students $(\approx 5 \%)$ found them similar. In line with these results, 23 students $(\approx 39 \%)$ found the lectures considerably more interesting, 29 thought they were more interesting $(50 \%), 5$ labelled them as being the same $(\approx 9 \%)$, while one student thought the lectures were more boring $(\approx 2 \%)$. These figures conspicuously testify to the fact that the vast majority of students found their more recent experience with grammar classes both different and more interesting in comparison to what they had encountered in their primary and/or secondary education. However, these results become more relevant if they are viewed in the light of the respondents' comments in the third question - the one that actually highlights the application of elements of popular culture as the main innovation in the two university grammar courses.

The third question was an open-ended one and it was given in the following form:

3) Please comment on the use of popular culture references (movie clips, song lyrics, film titles and quotes, cartoons, etc.) in English Grammar 1 and English Grammar 2 lectures.

Some of the representative responses to the third question include the following:

- Grammar has never been this interesting.

- It is very interesting and much easier to remember the rules.

- This approach makes grammar rules fun and easy to understand.

- I always thought grammar was boring, but it is much better this way...

- I especially liked the "South Park" clips and I always think of poor Kenny when discussing syntactic elements and semantic roles. This is something I always thought of in the second-year grammar classes too.

- Awsome!

$-\quad:)$

- In elementary school and high school we only had the traditional way, which was quite boring. This is much better and gives me more motivation to study grammar.

- Now I almost like grammar and I used to hate it. When I have to define or use a rule, I think of examples from the songs and films from the lecture.

- I was delighted when the professor played Katie Perry for us and then made us think of it in terms of grammar.

- I love cartoons and it was nice to see they could be used this way.

- Although I am kind of a traditional type when studying, I admit this was much better because it kept our attention for 90 minutes, which is, by the way, too long for a grammar lecture!

- It changed my view on modals! May the force be with you, especially in grammar! 
- Grammar classes in school were always useful, but extremely boring. When they promised at the beginning of GEJ1 that it would be interesting and connected to what we know from popular songs and films, I didn't really believe them, but it was really both useful and INTERESTING!

- I think the main advantage over the traditional method is keeping our attention and creating associations between grammar and what we like to watch or listen to, which is then great for remembering new rules!

- Traditionally, grammar is boring, although it was never really boring for me, I always like it anyway. I think I would've liked it at university too, but like this it was a real pleasure and I really enjoyed the classes! Bravo!

- The biggest advantage is that you can always remember the example from the class because it was always something we know from real life.

- Grammar somehow came alive! It was not just on paper anymore!

- Before this, I always had problems with grammar rules (I could not use them successfully in school and never had more than 3 or 4 from grammar tests, I was always stronger in speaking) and I was scared at the faculty at the beginning, but in the end I got a 9 from GEJ1 and 8 from GEJ 2 because the popular examples helped me to understand and use the rules better than before. I still remember many examples, especially from The Simpsons and South Park.

- It was gr8. Rewatched all Indiana Jones Movies after the class on reference.

- Me like it;)

Based on the students' responses, it is not difficult to conclude that the open-ended question provoked a number of positive comments that corroborate the hypothesis about the useful and entertaining nature of elements of popular culture in grammar classes at this level of education. It is worth mentioning that there were only three distinctly different comments that boil down to one of them: "I didn't find it that interesting, but it was OK, I guess...". Otherwise, the authors' main impression is that, owing to the stated positive characteristics of popular culture as an auxiliary and supplementary teaching tool, a considerable shift in attitude was achieved when it comes to students who had previously found grammar rules complex, boring and difficult to memorize. This is especially obvious when students themselves drew comparisons between their previous and new experience in studying grammar. Yet, even those who found their more traditional grammar classes useful and interesting, emphasized that the introduction of elements of popular culture only added to their positive experience.

Viewed alongside the figures in questions 1 and 2, this short survey proves the point that popular culture has an extremely positive effect on the attitudes of students of English Language and Literature when they encounter topics related to complex issues in grammar. 


\section{CONCLUSION}

Grammar rules are more often than not perceived by students as uninteresting, complex, abstract and difficult to understand, memorize and apply. This paper has, hopefully, proved - both through the presentation of representative examples and the students' comments in the survey - that elements of popular culture in teaching prescriptive and descriptive grammar at the undergraduate level are highly useful auxiliary learning tools, motivators, and, not less importantly, that they represent a special kind of "comic relief" - entertaining or humorous content in a more serious context. A memorable multimodal associative link is established between grammar rules, on the one hand, and well-known titles, lines and quotes from favourite films, uttered by famous performers or fictional characters, on the other. By establishing such a link, students are expected to accept grammar not as a self-sufficient isolated system, but an integral and lively part and basis of the contemporary language spoken and heard in the world of popular culture they are deeply immersed in. Thus, for instance, the varying complexity of the noun phrase structure shifts from being an abstract concept to a phenomenon observable and comprehensible by means of an easily memorized list of shorter and longer film titles ranging from Her, Avatar and The Dark Knight, through The Grand Budapest Hotel and Three Billboards Outside Ebbing, Missouri to The Man Who Knew Infinity. More generally, as Rets (2016) puts it, "popular culture, having global supranational character, giving priority to fashionable uses of words and emotionalism, might serve as a stronger encouragement for language acquisition" (Rets, 2016: 155).

The next step in establishing the place and function of popular culture in grammar instruction, and a complementary part of this study, would be a more comprehensive testing of students' impressions of and attitudes towards this kind of teaching at the university level, after they have encountered various methods and techniques throughout their previous education in primary and secondary school. In the long run, it would also be valuable to gather information on whether former students of English Language and Literature who attended the courses English Grammar 1 and English Grammar 2, once they have graduated, apply similar methods in their own present-day teaching practices, regardless of how advanced their students are or which educational level or profile they are involved in.

In this vein, reverting to the entertaining and relieving nature of popular culture in teaching and studying grammar, the final class in the course and this paper both end with Pictures 11 and 12, showing a promotional poster of Steven Spielberg's Jaws, with the hope that the ominous shark fin, for many representing 
grammar as something threatening lurking in a vast and seemingly endless ocean of rules, concepts and linguistic information, would actually turn out to be a cute friendly creature they would eventually come to enjoy the way they like their pet goldfish in an aquarium.

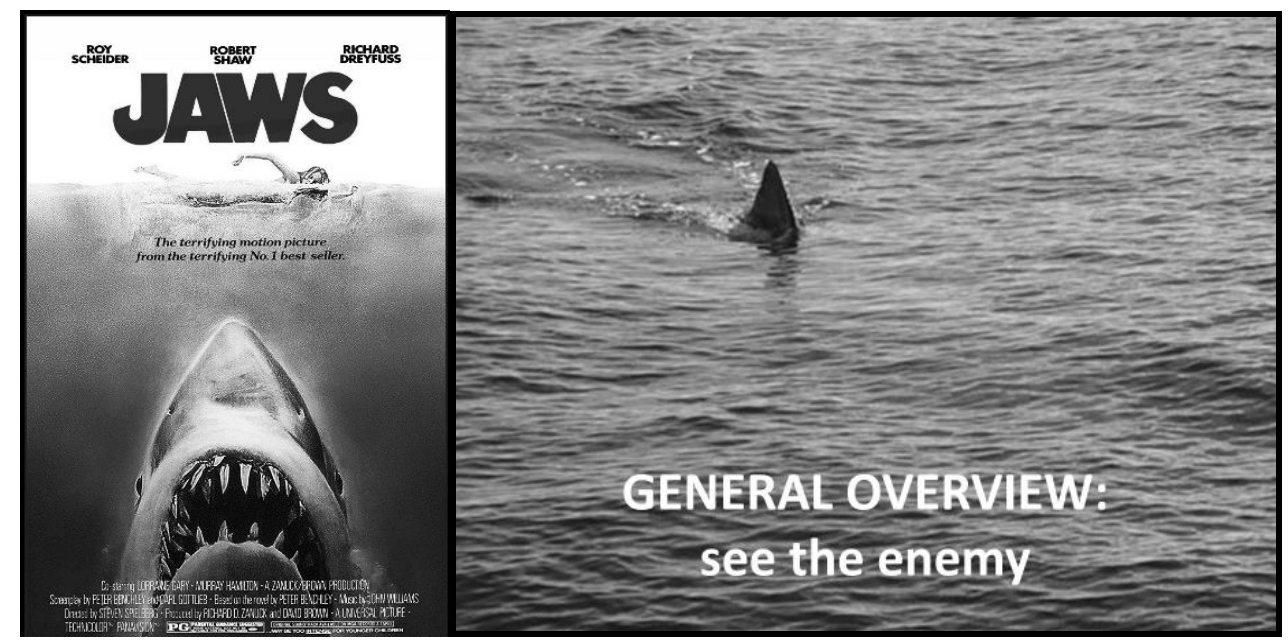

Picture 11: Grammar as a shark: see the apparent enemy

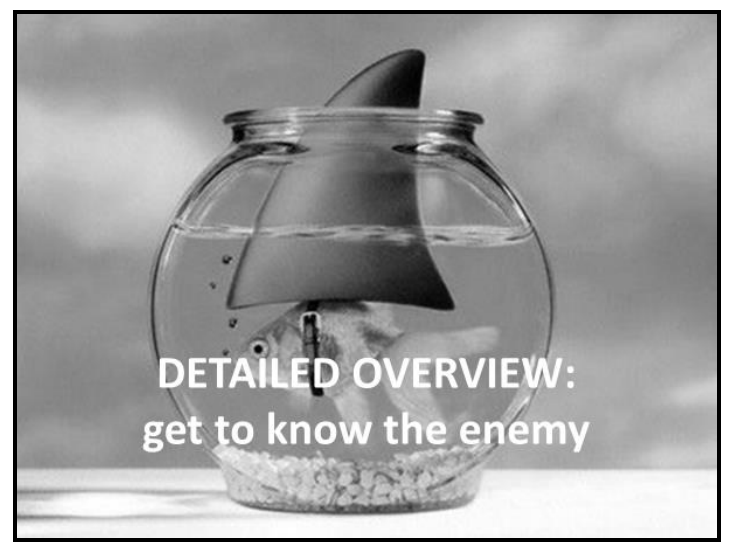

Picture 12: Grammar as a goldfish: get to know the real "enemy" 
Olga Panić Kavgić, Aleksandar Kavgić

\title{
ELEMENTI POPULARNE KULTURE U NASTAVI REČENIČNE STRUKTURE I GLAGOLSKIH KATEGORIJA ZA STUDENTE ENGLESKOG JEZIKA I KNJIŽEVNOSTI
}

\begin{abstract}
Rezime
Rad se bavi primenom elemenata popularne kulture u nastavi određenih oblasti gramatike engleskog jezika studentima prve godine osnovnih akademskih studija Engleskog jezika i književnosti na Odseku za anglistiku na Filozofskom fakultetu u Novom Sadu. Korpus razmatranih primera čine gramatički relevantni sadržaji iz odabranih popularnih filmova, televizijskih serija, dugometražnih animiranih filmova, filmskih naslova i slogana, dokumentarnih filmova, stripova, karikatura, šou programa, tekstova poznatih pop i rok pesama, koji su korišćeni kao pomoćni nastavni materijali tokom osamnaestogodišnjeg nastavnog iskustva autorâ rada na predmetima Gramatika engleskog jezika 1 i Gramatika engleskog jezika 2.

U uvodnom odeljku navedena je hipoteza i ciljevi koji se tiču dokazivanja primenjivosti popularne kulture u nastavi gramatike na visokoškolskom nivou, koja je zatim predstavljena u svetlu reformisanog nastavnog procesa. Date su osnovne teorijske postavke eksplicitnog naspram implicitnog, te preskriptivnog naspram deskriptivnog pristupa, s naglaskom na činjenici da su elementi popularne kulture kao pomoćno nastavno sredstvo najbolje primenjivi u okviru implicitnog i deskriptivnog pristupa. Ovaj odeljak se završava razmatranjem i definisanjem pojma i termina popularne kulture kao ključnog za razumevanje kriterijumâ za odabir primera predstavljenih u radu, te hronološkim pregledom uvođenja elemenata popularne kulture u tradicionalnu nastavu jezika.

Nakon opisa korpusa (npr. filmovi, serije, animirani i dokumentarni filmovi poput Ratova zvezda, Saut Parka, Šreka ili Planete Zemlje; stotine filmskih naslova i slogana; pesme kao što su Summer Wine ili Satisfaction) i kvalitativne metodologije istraživanja zasnovane na deskriptivnom predstavljanju odabranih primera i kasnije datih studentskih odgovora $\mathrm{u}$ kraćem upitniku, obrađenih kvalitativno i kvantitativno, u centralnom delu rada kroz mnogobrojne gramatički reprezentativne primere opisana je primena elemenata popularne kulture u obradi nastavnih jedinica „Osnovni gramatički pojmovi“ i „Glagol i glagolska sintagma“, u okviru predmeta Gramatika engleskog jezika 1. Teme koje su u radu predstavljene kroz prizmu elemenata popularne kulture pomoću ilustrativnih fotografija, slika, tabela i tekstualnih sadržaja, koji su inače na samom času dati kroz audiovizuelne multimodalne sadržaje, jesu sledeće: gramatika standardnog jezičkog varijeteta naspram „gramatikâ" nestandardnih varijeteta; rečenični konstituenti; gramatička dvosmislenost; sintagme i rečenice kao sintaksičke jedinice; vrste sintagmi u engleskom jeziku; glagoli, glagolska sintagma i glagolske kategorije - vreme, vid, način, stanje i modalnost.
\end{abstract}


Na kraju glavnog odeljka i, kasnije, u završnim razmatranjima, naglašen je i bitan motivišući faktor zabavne i neformalne prirode elemenata popularne kulture. Ovo je, između ostalog, potvrđeno i odgovorima dobijenim u kratkom elektronskom upitniku poslatom studentima koji su u poslednjih pet godina pohađali nastavu iz predmeta Gramatika engleskog jezika 1 i Gramatika engleskog jezika 2. Dobijeni odgovori obrađeni su kvantitativno (dva pitanja s odgovorima na Likertovoj skali) i kvalitativno (jedno pitanje o utiscima o primeni elemenata popularne kulture u nastavi).

U zaključku je istaknuto da primena ovakvih sadržaja u nastavi omogućuje studentima da gramatiku počnu da posmatraju kao integralni deo sveta koji ih okružuje, a ne kao samodovoljni izolovani sistem koji svojim obimom i kompleksnošću neretko izaziva strah, odbojnost i utisak da se radi o nečemu teško savladivom i odvojenom od praktične realnosti oličene, između ostalog, u i fenomenu popularne kulture. Potvrdu ovakvog stava predstavljaju i rezultati kratkog upitnika u kojem studenti u svojim komentarima iznose pohvale $\mathrm{i}$ ističu pozitivne strane ovakvog nastavnog procesa u odnosu na tradicionalniji metod. Na samom kraju, predloženi su mogući pravci za dalja istraživanja u ovoj aktuelnoj oblasti.

Ključne reči: nastava gramatike, engleski jezik, popularna kultura, kurs gramatike na osnovnim akademskim studijama, rečenična struktura, glagolska sintagma, gramatičko pravilo, povratne informacije od studenata

\section{SOURCES}

AZLyrics, available at www.azlyrics.com

Best Examples of Present Perfect Tense - Learn and teach English with videos, available at: https://www.youtube.com/watch?v=XUIJ9pBDlHs

Cartoon Stock, available at www.cartoonstock.com

Disney.com | The official home for all things Disney, available at: www.disney.com

DreamWorks Animation, available at: www.dreamworks.com

Hi and Lois, available at https://www.comicskingdom.com/hi-and-lois

Oscars.org | Academy of Motion Picture Arts and Sciences, available at: www.oscars.org

Pixar Animation Studios, available at: www.pixar.com

South Park Studios, available at: https://southpark.cc.com/

The Biggest Grammatical Mistakes in Songs We Love to Sing, available at:

https://www.dictionary.com/e/s/mistakes-in-songs/\#1

The Simpsons, available at:

https://www.youtube.com/channel/UC6v9JbzcdEcZsXcVpBsMq-g 
A number of pictures, photographs and captions in this article have been downloaded from Google Images and Google Videos. The authors of the paper do not lay any claim on the authorship of the images - they were utilized here for illustrative purposes within the common practice of fair use in academic research.

\section{REFERENCES}

Bodrič, R. (2018). Implicit or explicit grammar teaching - which is to be?. In: Polovina, V., Kovačević, B. \& Božović, Đ. (eds.) (2018). International Congress Applied Linguistics Today Challenges of Modern Times (6; 2018; Beograd) Language, Literature and Interdisciplinarity: book of abstracts / The Sixth International Congress Applied Linguistics Today, 12-13 October 2018. Beograd: Filološki fakultet. 7.

Chalker, S. (1992). A Student's English Grammar Workbook. London: Longman. Close, R. (1974). A University Grammar of English Workbook. London: Longman. Cortazzi, M.-Lin, L. (1999). Cultural mirrors. In: Hinkel, E. (ed.). (1999). Culture in Second Language Teaching and Learning. Cambridge: Cambridge University Press. 196-219.

Ćurčić, J. (2016). Popularna kultura kao motivaciono sredstvo u srednjoj školi (Nepublikovan masterski rad). Filozofski fakultet, Univerzitet u Novom Sadu, Novi Sad.

Dejić, V. (2013). Tehnike podučavanja gramatike engleskog jezika u osnovnim školama (Nepublikovan masterski rad). Filozofski fakultet, Univerzitet u Novom Sadu, Novi Sad.

Duff, P. A.-Zappa-Hollman, S. (2013). Using popular culture in language teaching. In: Chapelle, C. A. (ed.). (2013). The Encyclopedia of Applied Linguistics. Chichester: Wiley-Blackwell. 5997-6002.

Dujić, R. (2016). Kreativni pristup nastavi gramatike engleskog jezika na nivoima A1 i A2 (Nepublikovan masterski rad). Filozofski fakultet, Univerzitet u Novom Sadu, Novi Sad.

Đurić, R.-Šević, R. B. (2001). English Grammar Introductory Course: Workbook. Novi Sad: Filozofski fakultet.

Đurić, R.-Šević, R. B. (2006). A Student's Workbook of English Grammar. Novi Sad: Filozofski fakultet, Futura publikacije.

Gajdoš, S.-Korpaš, O. (2019). Teaching English tenses through popular movies - a case study. Zbornik Odseka za pedagogiju, 28, 137-160. 
Glušac, T.-Pilipović, V. (2019). Pedagoška uverenja studenata engleskog jezika podložnost promeni i izvori promena. Zbornik radova Filozofskog fakulteta u Prištini, 49/1, 69-88.

Graus, J.-Coppen, P. (2016) Student teacher beliefs on grammar instruction. Language Teaching Research, 20/5, 571-599.

Greenbaum, S.-Quirk, R. (1990). A Student's Grammar of the English Language. London: Longman.

Harmer, J. (2003). Popular culture, methods, and context. ELT Journal, 57/3, 288294.

Hewings, M. (2013). Advanced Grammar in Use. Third Edition. Cambridge: Cambridge University Press.

Hofmann, J. (2018). Pixar films, popular culture, and language teaching: The potential of animated films for Teaching English as a Foreign Language. Global Studies of Childhood, 8/3, 267-280.

Hua, C.-Li, B. (2015). Bringing fun and meaning into grammar learning: A case study of a secondary-level EFL class in Hong Kong. Cogent Education, 2. doi:10.1080/2331186X.2015.1111039

Kirby, D. (1976). Popular culture in the English classroom. The English Journal, 65/3, 32-34.

Lefstein, A.-Snell, J. (2011). Promises and problems of teaching with popular culture: A linguistic ethnographic analysis of discourse genre mixing in a literacy lesson. Reading Research Quarterly, 46/1, 40-69.

Liu, Y.-Lin, A. M. Y. (2017). Popular culture and teaching English to speakers of other language (TESOL). In: Thorne, S. and May, A. (eds.). (2017). Language, Education and Technology. Third Edition. Berlin: Springer. 87102.

Longman Dictionary of Contemporary English on CD-ROM. Updated Edition. (2009). Harlow: Pearson Longman.

Luo, J. J. (2014). Using popular culture to promote learning in EFL classrooms: A case study. Procedia - Social and Behavioral Studies, 112, 209-218.

Marjanović, T. (2017). English lessons from the Big Bang Theory. In: Parezanović, T., Budinčić, V. \& Karić, D. B. (eds.). (2017). Language, Literature, and Popular Culture. Proceedings from the Fifth International Conference at the Faculty of Foreign Languages: Language, Literature, and Popular Culture, 30 September - 1 October 2016. Beograd: Alfa BK University. $25-48$. 
Nedić, J. (2014). Primena vizuelnih sredstava u nastavi gramatike engleskog jezika na osnovnoškolskom nivou (Nepublikovan masterski rad). Filozofski fakultet, Univerzitet u Novom Sadu, Novi Sad.

Novakov, P. (2012). Studije anglistike u reformisanoj univerzitetskoj nastavi. U: Dimitrijević, B. (ured.). (2012). Filologija i univerzitet. Tematski zbornik radova. [Nauka $i$ savremeni univerzitet 1]. Niš: Filozofski fakultet Univerziteta u Nišu. 630-650.

Panić Kavgić, O. (2014). Jezička kreativnost u formiranju filmskih naslova na engleskom jeziku i njihovom prevođenju na srpski. U: Prćić, T.-Marković, M. i dr. (ured.). (2014). Engleski jezik $i$ anglofone književnosti u teoriji $i$ praksi. Zbornik u čast Draginji Pervaz. Novi Sad: Filozofski fakultet. 399418.

Panić Kavgić, O.-Kavgić, A. (2018). Creativity in film taglines: Extralinguistic, textual and linguistic analysis. Godišnjak Filozofskog fakulteta u Novom Sadu, 43/1, 101-125.

Phipps, S.-Borg, S. (2009). Exploring tensions between teachers' grammar teaching beliefs and practices. System, 37/3, 380-390.

Quirk, R.-Greenbaum, S. (1973). A University Grammar of English. London: Longman.

Rets, I. (2016). Teachers' perceptions on using popular culture when teaching and learning English. Procedia - Social and Behavioral Sciences, 232, 154160.

Swan, M. (2005). Practical English Usage. Third Edition. Oxford: Oxford University Press.

Vince, M.-Sunderland, P. (2003). Advanced Language Practice. Second Edition. Oxford: Macmillan Education. 